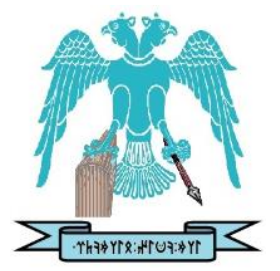

JOURNAL OF ENERGY SYSTEMS

2020, 4(2)

\title{
Design of an innovative PV/T and heat pump system for greenhouse heating
}

\author{
Meltem Koşan \\ Gazi University, Natural and Applied Science Institute, Ankara, Turkey, mltmkosan@gmail.com \\ Ahmet Eren Akkoç \\ Gazi University, Technology Faculty, Energy Systems Engineering, Ankara, Turkey, akeren3736@gmail.com \\ Ebubekir Dişli \\ Gemak Food Industry Machinery, Ankara, Turkey, ebubekir.disli@gmail.com \\ Mustafa Aktaş \\ Gazi University, Technology Faculty, Energy Systems Engineering, Ankara, Turkey, mustafaaktas@gazi.edu.tr
}

$\begin{array}{rr}\text { Submitted: } & 21.05 .2020 \\ \text { Accepted: } & 20.06 .2020 \\ \text { Published: } & 30.06 .2020\end{array}$

\begin{abstract}
The very high annual heat demand of greenhouses is the most critical factor that increases production costs. Conventional methods are generally used to obtain the optimum temperature required for greenhouses. In these systems, greenhouse air is heated by a boiler and pipe networks are connected to it, and in this way, most of the heat energy is transferred from the greenhouse ceiling to the atmosphere. In addition, in the greenhouse, not only the air but also the soil should be heated in order not to spoil the roots of the plants. The objective of this research is to provide sustainable heating for greenhouse applications. For this purpose, an innovative heating system has been designed for greenhouse heating by using of solar energy and heat pump technologies. In this study, a new approach was presented by designing a novelty heat pump flow for the heat required in the greenhouse. With this design, not only greenhouse air but also the soil will be heated and the best conditions for the development of plants will be provided. In the system, an ethylene glycol water mixture was used to prevent damage caused by freezing. In addition, it is designed to provide sustainability with an auxiliary heater when solar radiation is insufficient. It is highly recommended to apply this presented system for all greenhouse types.
\end{abstract}

Keywords: Energy efficiency, Greenhouse heating, Heat pump, Solar energy

Cite this paper as: $\quad$ Koşan, M., Akkoç, A.E., Dişli, E., \& Aktaş, M. Design of an innovative PV/T and heat pump system for greenhouse heating. Journal of Energy Systems 2020, 4(2), 58-70, DOI: 10.30521/jes.740587

(C) 2020 Published by peer-reviewed open access scientific journal, JES at DergiPark (https://dergipark.org.tr/en/pub/jes)

\begin{tabular}{r|l} 
Nomenclature & \\
\hline$C O P$ & Coefficient of performance \\
$E G P_{h p}$ & Performance coefficient of heat pump system \\
$G H$ & Ethylene glycol water mixture \\
$H P$ & Heenhouse heating \\
$P V$ & Photovoltaic \\
$P V / T$ & Photovoltaic thermal \\
$S A H$ & Solar air heater \\
Symbols & \\
\hline$A_{\text {col,surface }}$ & Collector surface area (m2) \\
$A_{\text {floor }}$ & Floor area of the greenhouse (m2) \\
$A_{\text {surface }}$ & Total surface area where greenhouse heat losses \\
$A_{\text {hx,surface }}$ & occur (m2) \\
$A_{\text {pipe }}$ & Pipe area (m2)
\end{tabular}

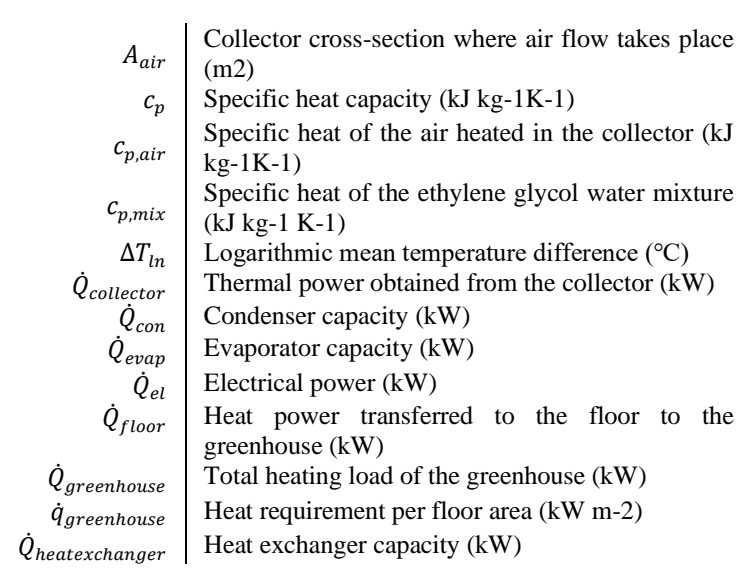




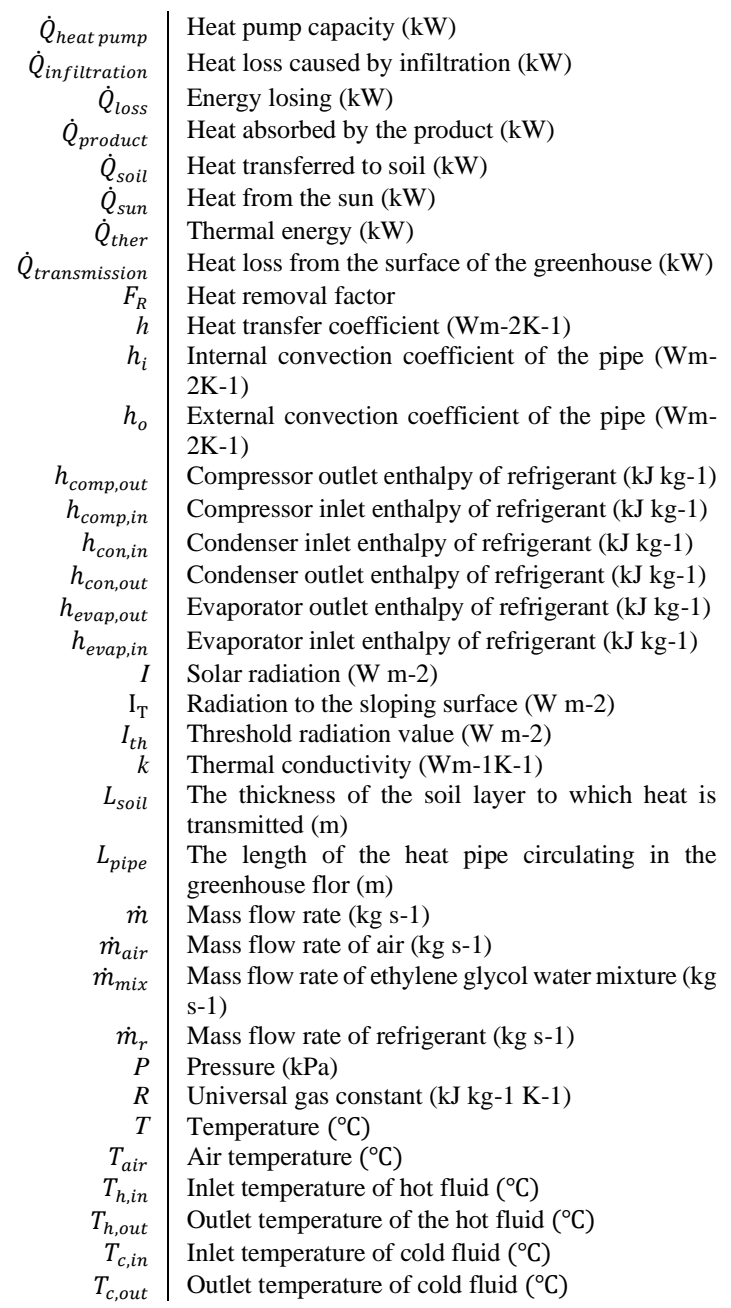

\begin{tabular}{|c|c|}
\hline$T_{\text {col,out }}$ & Collector outlet temperature of air $\left({ }^{\circ} \mathrm{C}\right)$ \\
\hline$T_{c o l, i n}$ & Collector inlet temperature of air $\left({ }^{\circ} \mathrm{C}\right)$ \\
\hline$T_{\text {greenouse, in }}$ & Ambient temperature inside the greenhouse $\left({ }^{\circ} \mathrm{C}\right)$ \\
\hline $\mathrm{T}_{\text {greenhouse,out }}$ & $\begin{array}{l}\text { Environmental temperature outside the greenhouse } \\
\left({ }^{\circ} \mathrm{C}\right)\end{array}$ \\
\hline$T_{\text {mix }, \text { out }}$ & $\begin{array}{l}\text { Outlet temperature of ethylene glycol water } \\
\text { mixture from condenser of heat pump }\left({ }^{\circ} \mathrm{C}\right)\end{array}$ \\
\hline$T_{m i x, i n}$ & $\begin{array}{l}\text { Inlet temperature of ethylene glycol water mixture } \\
\text { pump }\left({ }^{\circ} \mathrm{C}\right)\end{array}$ \\
\hline$T_{\text {mix }, \text { evap,out }}$ & $\begin{array}{l}\text { Outlet temperature of ethylene glycol water } \\
\text { mixture from evaporator of heat pump }\left({ }^{\circ} \mathrm{C}\right)\end{array}$ \\
\hline$T_{\text {pipe }}$ & $\begin{array}{l}\text { Average surface temperature of the heat pipe } \\
\text { circulating in the greenhouse ground }\left({ }^{\circ} \mathrm{C}\right)\end{array}$ \\
\hline$U_{h x}$ & $\begin{array}{l}\text { Total heat transfer coefficient of the heat exchanger } \\
\text { (W m-2K-1) }\end{array}$ \\
\hline$U_{\text {total }}$ & $\begin{array}{l}\text { Total heat transfer coefficient of the greenhouse }(\mathrm{W} \\
\mathrm{m}-2 \mathrm{~K}-1)\end{array}$ \\
\hline$U_{l}$ & Total heat loss in the collector (W m-2K-1) \\
\hline$\dot{V}$ & $\begin{array}{l}\text { Volumetric flowrate of air passing through the } \\
\text { collector (m3s-1) }\end{array}$ \\
\hline$\dot{V}_{\text {pump }}$ & $\begin{array}{l}\text { Volumetric flowrate of the fluid passing through } \\
\text { the pump (m3s-1) }\end{array}$ \\
\hline V & Velocity (m s-1) \\
\hline$V_{\text {air }}$ & Air velocity (m s-1) \\
\hline$\dot{W}_{\text {comp }}$ & Compressor capacity (kW) \\
\hline$\dot{W}_{f a n}$ & Fan capacity (kW) \\
\hline $\begin{array}{c}\dot{W}_{\text {pump }} \\
\text { Greek }\end{array}$ & Pump capacity (kW) \\
\hline$\alpha_{s}$ & $\begin{array}{l}\text { Absorption rate of solar radiation energy to the } \\
\text { surface }\end{array}$ \\
\hline$\tau$ & Solar irradiation transmissivity \\
\hline$\rho$ & Density (kgm-3) \\
\hline$\rho_{\text {air }}$ & Air density $(\mathrm{kgm}-3)$ \\
\hline$\rho_{\text {mix }}$ & Density of ethylene glycol water mixture ( $\mathrm{kg} \mathrm{m}-3)$ \\
\hline$\sigma$ & Stefan-Boltzmann constant (W m-2K-4) \\
\hline$\varepsilon$ & Diffusivity of pipe \\
\hline$\eta_{c}$ & Collector total efficiency \\
\hline$\eta_{f}$ & Fan efficiency \\
\hline$\eta_{p}$ & Pump efficiency \\
\hline$\eta_{\mathrm{PV} / \mathrm{T}}$ & $\mathrm{PV} / \mathrm{T}$ efficiency \\
\hline
\end{tabular}

\section{INTRODUCTION}

Greenhouses are structures with various forms of protection for plants that cannot be grown outside due to adverse climates, diseases and harmful factors. Greenhouses provide to obtain the maximum efficiency from planting, creating better growing conditions. The greenhouse climate, which has the most suitable value with regard to temperature, ventilation, light, and relative humidity, influences the achievement of the production [1]. Temperature is one of the most major climatic factors that must be created in the greenhouse. Staminal activities of plants generally decelerate at $7{ }^{\circ} \mathrm{C}$ and stop at $0{ }^{\circ} \mathrm{C}$. In greenhouses, the minimum temperature during the plant period should be $10^{\circ} \mathrm{C}$. For the seedling period, the temperature varies between $15-25^{\circ} \mathrm{C}$ depending on the seedling [2]. Therefore, it is the soil temperature which is above $10^{\circ} \mathrm{C}$ will affect positively the plant growth. Heating is needed to keep the greenhouse environment at a certain temperature. The use of fossil fuels to meet the heating need increases greenhouse energy consumption and carbon footprint $[3,4]$.

Many systems have been researched in the literature to diminish the amount of energy consumption for heating the greenhouses and to meet the heating needs. Esen and Yuksel (2013) designed a system for heating a greenhouse, including a horizontal heat exchanger and a biogas solar and ground source heat pump (HP) heating system, and showed that alternative energy resources may be effectively conducted 
for greenhouse heating (GH) [5]. Attar and Farhat (2015) experimentally researched the efficiency of a solar water system based on the heat exchangers combined in the greenhouse for heating and soil heat storage. According to the results, the efficiency of the heating system for a $10 \mathrm{~m}^{3}$ greenhouse was about 64.9\% in December and about $133.6 \%$ in April [6]. Yildirim and Bilir (2017) examined the photovoltaic panel (PV) assisted HP for cooling and heating loads in a greenhouse in Turkey. Sixty-six PVs were used for the electrical supply of the HP in the cultivation of three crops, cucumber, tomato, and lettuce. With this system, it was obtained that it could meet $33.2-67.2 \%$ of greenhouse demand [7]. Aye et al. (2010) studied the financial and environmental feasibility of an air-to-water HP system for a $4000 \mathrm{~m}^{2}$ greenhouse. They observed that HP system had a simple payback term about six years and reduced LPG consumption by $16 \%$ [8]. Joudi and Farhan (2014) experimentally studied a greenhouse consisting of six solar air heaters (SAHs) bonded in parallel for a traditional greenhouse and enclosing $45 \%$ of the greenhouse roof. SAH indicated that the greenhouse provides daily heating load, and the energy stored from the heater and the solar heat in the greenhouse meet all daily heating requirements by around $46 \%$ [9]. Mohsenipour et al. (2020) carried out theoretical research on growing lettuce and tomatoes using a sun-based greenhouse using a high-efficiency combination of cooling, heating, and power system. Annual electricity and water consumption produced by the turbine for tomatoes and lettuce was calculated as $2139233 \mathrm{kWh}$ and $3090333 \mathrm{kWh}$ with the use of R134a as refrigerant, compared to the conventional system, the annual fuel and water consumption was recorded as $1.841 .29 \mathrm{~m}^{3}$ and $266.5 \mathrm{~m}^{3}$ for lettuce and as $10.675 .04 \mathrm{~m}^{3}$ and $141.01 \mathrm{~m}^{3}$ for tomatoes. In the cost assessment, the payback period for lettuce and tomato scenarios was determined as 12 and 15 years, respectively [10].

Baddadi et al. (2018) experimentally investigated a novelty hydroponic greenhouse and a new SAH with latent heat energy storage. The surplus amount of thermal energy was stored as latent heat in the phase change material. The results obtained showed that the average daily thermal efficiency of the SAH with latent heat storage varies among $0.29 \%$ and $0.38 \%$, and the annual energy production decreases by more than $4600 \mathrm{kWh}$ thanks to solar heating [11]. Zhang et al. (2015) designed and researched a low-cost seasonal solar collector-assisted earth heat storage system used for GH. After the tests, it was proved to be possible for the system to store seasonal thermal energy that could partially solve the problem of solar heat demand and supply imbalance between summer and winter. The energy consumption of the designed system and the traditional solar heating system were compared under the same condition and it was stated that when the indoor air temperature of the greenhouse was kept above $12{ }^{\circ} \mathrm{C}$ throughout the year, the energy saving was $27.8 \mathrm{kWh}[12]$.

Considering the above studies, fuel consumption, energy efficiency, and costs are significant in heating the greenhouses. In this study, an innovative heating system was designed and recommended by combining solar energy and HP technology to meet the heat energy of greenhouses. With this design, it is aimed to provide the best conditions for the development of plants by heating not only greenhouse air but also the soil. The originality of this study is that HP system is designed as a closed-loop and exchanges heat between two different heat transfer fluids. A novelty flow design is introduced in HP system.

\section{MATERIAL AND METHOD}

While the greenhouse temperature depends on the variety and development stage of the plant species, it should generally not fall below $15^{\circ} \mathrm{C}$ and not exceed $30^{\circ} \mathrm{C}$ for the plants. At night, the greenhouse temperature should be no more than $8{ }^{\circ} \mathrm{C}$ lower than the daytime value. While the optimum temperature for rooting plants is $18{ }^{\circ} \mathrm{C}$, the temperature required for fruit and flower is around $20^{\circ} \mathrm{C}$ [13]. In Table 1 , there are various plant species and the required temperature values for the production of these plants. It can be seen in Table 1 that plants have different production temperatures. The energy values of the designed system will vary depending on the size of the system, the structure of the greenhouse, the type of plant, and the provision of suitable temperature conditions for its development. 
Table 1. Suitable temperature ranges for the production of some plant species and temperature values required for the start of heating [14]

\begin{tabular}{lcc}
\hline Product & Suitable temperatures for production $\left({ }^{\circ} \mathrm{C}\right)$ & Heating start temperature $\left({ }^{\circ} \mathrm{C}\right)$ \\
\hline Pea & $16-20$ & 3 \\
Pepper & $20-25$ & 8 \\
Tomato & $20-24$ & 7 \\
Beans & $18-30$ & 8 \\
Spinach & $15-18$ & -2 \\
Pumpkin & $25-35$ & 8 \\
Watermelon & $23-28$ & 10 \\
Melon & $25-30$ & 9 \\
Celery & $18-25$ & 5 \\
Lettuce & $14-18$ & 10 \\
Eggplant & $22-27$ & 9 \\
Chard & $18-22$ & -4 \\
Cucumber & $20-25$ & 10 \\
\hline
\end{tabular}

In the designed system, both soil and air are heated in order to develop the plants in a short time and quickly. The soil should be kept at the temperature values given in Table 2 for the healthy development of the plant. In cold winter seasons, the heat requirement of the plant is provided more easily and highly efficiently with the heating of the soil.

Table 2. Suitable soil temperatures for germination of vegetable seeds [15]

\begin{tabular}{lccc}
\hline Crops & Minimum $\left({ }^{\circ} \mathrm{C}\right)$ & Optimum range $\left({ }^{\circ} \mathrm{C}\right)$ & Maximum $\left({ }^{\circ} \mathrm{C}\right)$ \\
\hline Asparagus & 10 & $24-29$ & 35 \\
Beans, Lima & 16 & $24-29$ & 29 \\
Beans, Snap & 16 & $24-29$ & 35 \\
Beets & 4 & $18-29$ & 35 \\
Broccoli & 4 & $16-29$ & 35 \\
Cabbage & 4 & $16-29$ & 35 \\
Carrots & 4 & $18-29$ & 35 \\
Cauliflower & 4 & $18-29$ & 35 \\
Celery & 4 & NA & NA \\
Chard, Swiss & 4 & $18-29$ & 35 \\
Corn & 10 & $18-35$ & 41 \\
Cucumbers & 16 & $18-35$ & 41 \\
Eggplant & 16 & $24-29$ & 35 \\
Garlic & 0 & $18-29$ & 35 \\
Leeks & 0 & $18-29$ & 35 \\
Lettuce & 0 & $16-24$ & 29 \\
Muskmelons (Cantaloupe) & 16 & $24-29$ & 41 \\
Okra & 16 & $29-35$ & 41 \\
Onions & 0 & $18-29$ & 35 \\
Parsley & 4 & $18-29$ & 35 \\
Parsnips & 0 & $18-24$ & 29 \\
Peas & 4 & $18-24$ & 29 \\
Peppers & 16 & $18-24$ & 35 \\
Pumpkins & 16 & $29-35$ & 41 \\
Radishes & 4 & $18-29$ & 35 \\
Spinach & 0 & $18-24$ & 24 \\
Squash & 16 & $29-35$ & 41 \\
Tomatoes & 10 & $18-29$ & 35 \\
Turnips & $16-35$ & 41 \\
Watermelons & $24-35$ & 41 \\
\hline & & & \\
& 16 & 16 & \\
\hline
\end{tabular}

In greenhouses, an external heating application should be done in order not to fall below $15^{\circ} \mathrm{C}$ in general. Especially on winter days, meeting the heat requirement of the greenhouse with only solar radiation can be insufficient. While generating electricity more efficiently with a photovoltaic thermal (PV/T) hybrid system, heat energy can also be produced. The use of PV/T hybrid systems in GH provides advantages in many ways. In the design, the heat energy lost by the greenhouse through transmission, convection, 
and thermal radiation will be met by solar energy and HP system. It should be preferred that the fuel to be used in greenhouses heating should be low cost, high thermal value and easy to obtain and not harm the environment.

However, harmful gases resulting from combustion by using fossil fuels cause environmental pollution. In the system designed as shown in Fig. (1), the heat required for the greenhouse is obtained from a clean energy source. With the designed HP system, both the internal environment of the greenhouse and the soil are heated. Thanks to the floor heating system, the heat can be distributed homogeneously. Even in winter days, the system is not affected by weather conditions and seasonal changes of the temperature.

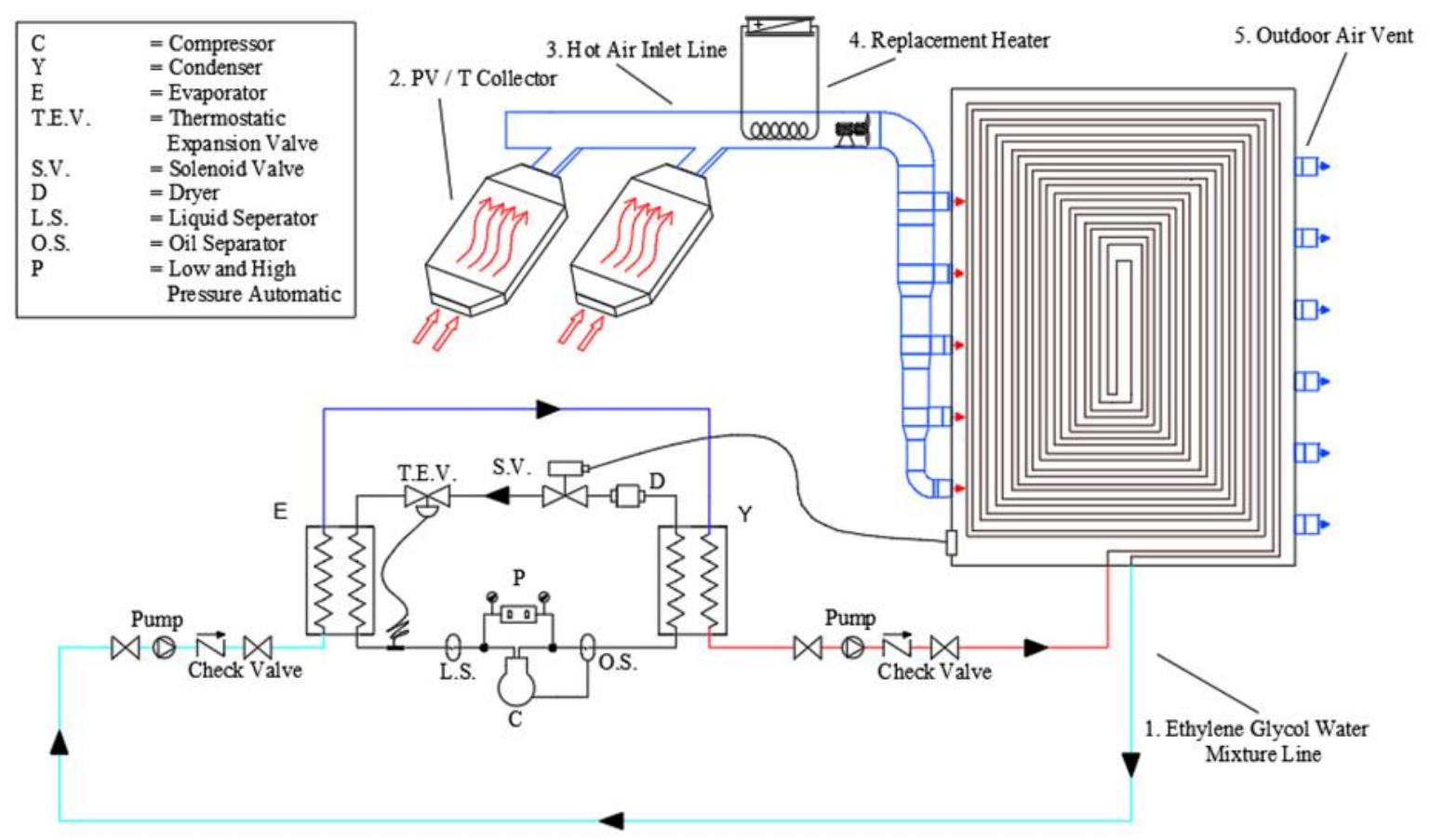

Figure 1. Schematic diagram of the system designed for greenhouse heating

As seen in Fig. (1), the heating need of the greenhouse is met by using the heat energy from the designed HP system and PV/T panel. When the solar irradiation is insufficient, the auxiliary heater shown in Fig. (1) will be operated. It will be ensured that the heat required for the greenhouse is not interrupted. The heat obtained from the PV/T panels is transferred to the greenhouse interior environment by means of air ducts. The air, which cools down in the greenhouse over time, is discharged to the outside environment via the outdoor air louvers. While providing the heating of the greenhouse with PV/T panels, the fresh air requirement of the greenhouse is also met.

Another system used to meet the heat loss that occurs in the greenhouse in the system is transferring heat to ethylene glycol water mixture (EGWM) from the condenser of HP. In the system, the operation of HP is controlled with the thermostat in the greenhouse. In cases where the heat required for GH is insufficient, HP system is operated. HP system is designed as a closed-loop and exchanges heat between two different heat transfer fluids. The first of these fluids is the refrigerant that extracts heat from the evaporator and transfers it to the condenser. The second is the EGWM that takes heat from the condenser and throws it into the greenhouse, forming again the waste heat source for the evaporator.

In the first heat transfer fluid loop, the evaporator extracts heat from EGWM and transfers it to the refrigerant. Meanwhile, refrigerant fluid passing from liquid phase to gas phase is compressed in the compressor and then sent to the condenser after its temperature and pressure are increased. Hightemperature refrigerant transfers heat to the floor heating line, in which there is EGWM. The transferred heat energy is used to heat the greenhouse through the pipes laid on the floor of the greenhouse. The 
fluid circulating in the pipes laid on the floor of the greenhouse returns to the soil to heat the soil and completes the cycle after transferring heat into the greenhouse as natural convection and thermal radiation.

In the second heat transfer fluid loop, EGWM creates the waste heat source for the evaporator after transferring its heat to the greenhouse. In other words, EGWM first cools in the greenhouse, by throwing its heat to the soil and air, and then it cools down again in the evaporator and enters the condenser, where it extracts the heat and completes the cycle. The originality of this design is that EGWM coming out of the evaporator enters the condenser and this method is a new approach in HP systems.

While the solar energy system to be used in the design will meet some of the heating requirements, the electrical energy produced will be used to meet the electrical loads such as fan, compressor, pump, and lighting to be used in the system.

\subsection{Energy Analysis}

The heat loads occurring in the greenhouse are given in Fig. (2). In addition to the heat losses arising from the greenhouse surfaces, the heat losses that occur while providing the air needed by the plants and the required heat requirement are available.

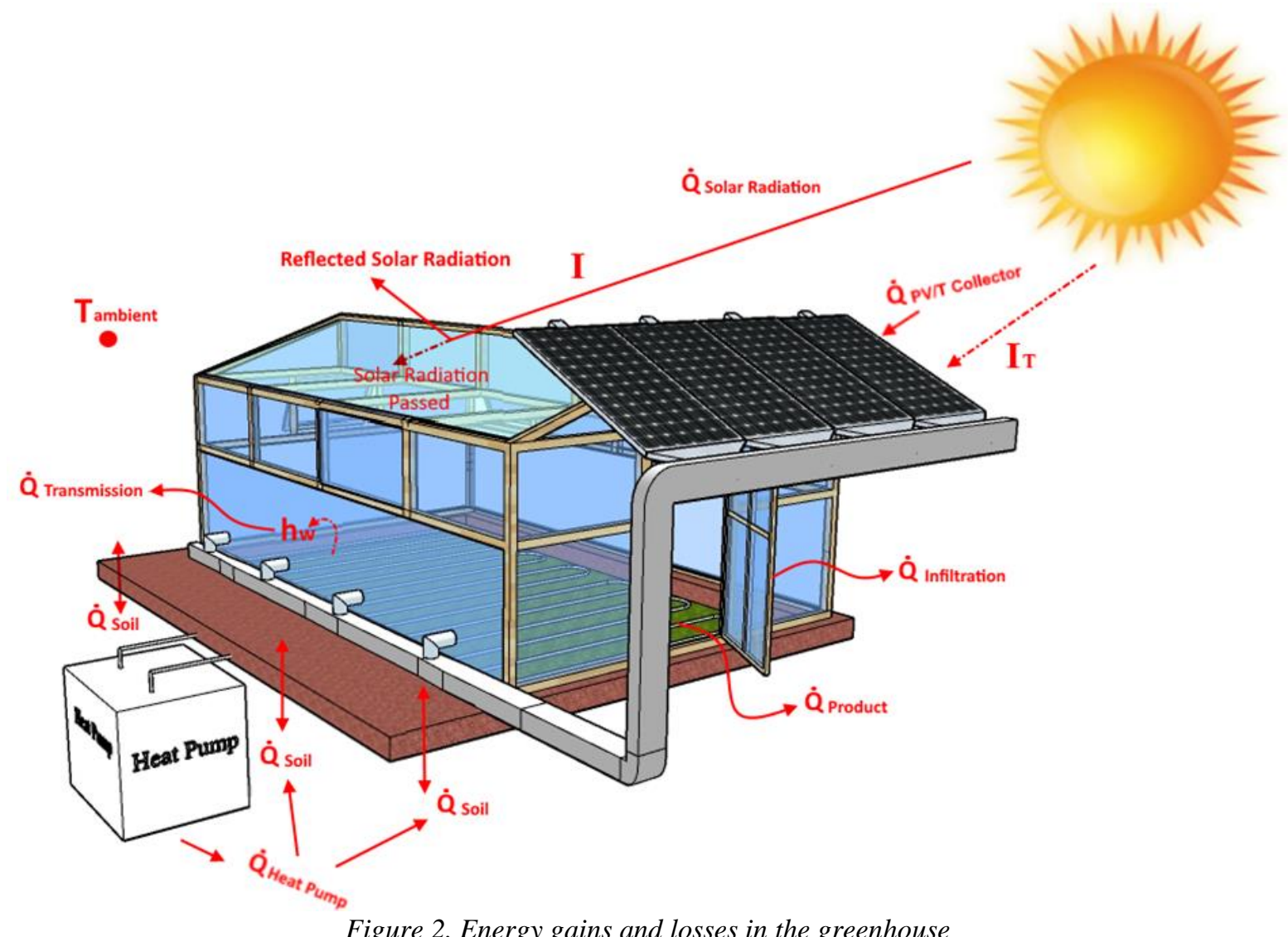

Fig. (3) shows the heat transfer mechanism that can occur in the designed greenhouse energy system. The energy equations required for the designed system for $\mathrm{GH}$ are given below. 


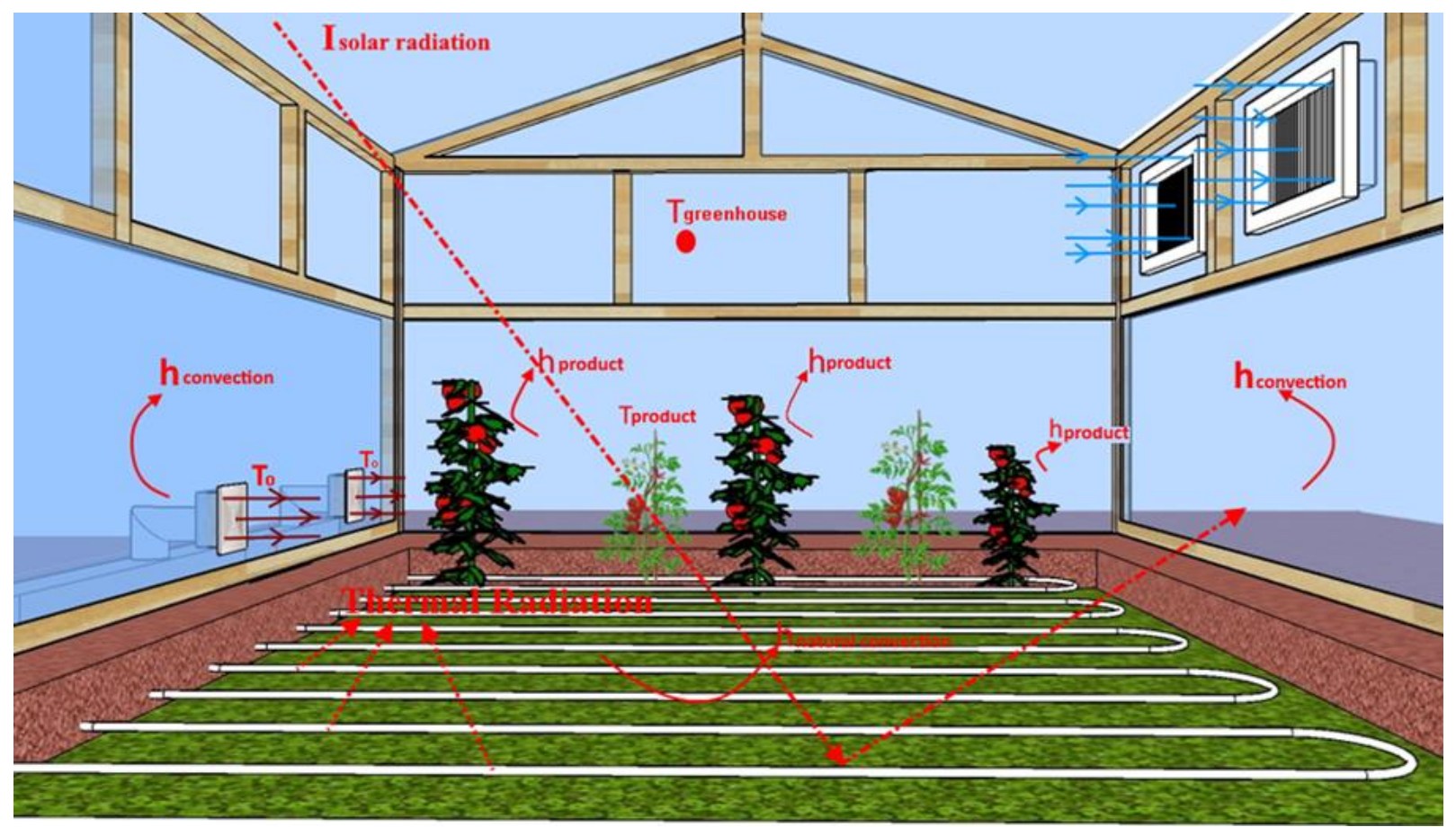

Figure 3. Heat transfer mechanisms in the greenhouse

The heat energy balance occurring in the greenhouses can be stated with the following equation as can be noted in Fig. (2):

$$
\dot{Q}_{\text {collector }}+\dot{Q}_{\text {heat pump }}=\dot{Q}_{\text {transmission }}+\dot{Q}_{\text {infiltration }}+\dot{Q}_{\text {product }}+\dot{Q}_{\text {soil }}
$$

Since greenhouses are covered with materials that can penetrate sunlight, they can use some solar energy naturally and the expression of the heat load to be met:

$$
\dot{Q}_{\text {greenhouse }}=\dot{Q}_{\text {loss }}-\dot{Q}_{\text {sun }}
$$

In order to calculate the HP and PV/T collector capacities, the total heat requirement must first be known. The heat load that must be met in greenhouses can be calculated as follows [16]:

$$
\begin{gathered}
\dot{q}_{\text {greenhouse }}=\frac{A_{\text {surface }}}{A_{\text {floor }}} U_{\text {total }}\left(T_{\text {greenouse, in }}-T_{\text {greenhouse,out }}\right)-\left(I \tau \alpha_{s}\right) \\
\dot{Q}_{\text {greenhouse }}=\dot{q}_{\text {greenhouse }} A_{\text {floor }}
\end{gathered}
$$

The thermal power required to heat the greenhouse calculated with Eq. (4) will be met by the PV/T panel and HP system:

$$
\dot{Q}_{\text {greenhouse }}=\dot{Q}_{\text {collector }}+\dot{Q}_{\text {heatpump }}
$$

The heat collected from the PV/T panel in this designed greenhouse system is expressed as:

$$
\dot{Q}_{\text {collector }}=\dot{m}_{\text {air }} c_{p, \text { air }}\left(T_{\text {col,out }}-T_{\text {col,in }}\right)
$$

here the mass flow of air $\dot{m}_{\text {air }}$ is determined as in the equation given below [17]:

$$
\dot{m}_{\text {air }}=\rho_{\text {air }} \dot{V}_{\text {air }} A_{\text {air }}
$$


The density of air $\rho_{\text {air }}$ is can be expressed:

$$
\rho_{\text {air }}=P / R\left(T_{\text {air }}+273.15\right)
$$

The specific heat of the air varies with temperature and can be found as below [18]:

$$
c_{p, a i r}=1009.26-0.0040403 T_{a i r}+0.00061759 T_{\text {air }}{ }^{2}-0.0000004097 T_{a i r}{ }^{3}
$$

The surface area of the PV/T panel used in GH can be found with the equation given below:

$$
A_{\text {colssurface }}=\frac{\dot{Q}_{\text {collector }}}{\mathrm{I}_{\mathrm{T}} \mathrm{n}_{c}}
$$

The total efficiency of the PV / T system used to meet the electricity and heat needs of the greenhouse are defined as follows [18]:

$$
\eta_{P V / T}=\frac{\dot{Q}_{\text {ther }}+\dot{Q}_{e l}}{I A_{\text {col,surface }}}
$$

The temperature difference of a known collector inlet temperature in the collector [19]:

$$
\begin{gathered}
\Delta T=\left(T_{\text {col,out }}-T_{\text {col,in }}\right)=\frac{\mathrm{F}_{\mathrm{R}} A_{c o l, s u r f a c e}(\tau \alpha) \mathrm{I}_{\mathrm{T}}}{\dot{m}_{\text {air }} c_{p, \text { air }}}-\frac{\mathrm{F}_{\mathrm{R}} A_{\text {col,surface }}(\tau \alpha) \mathrm{I}_{\mathrm{th}}}{\dot{m}_{\text {air }} c_{p, \text { air }}} \\
I_{\text {th }}=U_{l} \frac{\left(T_{\text {col,in }}-T_{\text {air }}\right)}{\tau \alpha}
\end{gathered}
$$

The power of the fan circulating hot air for the GH can be calculated with the following equation:

$$
\dot{W}_{f a n}=\frac{\dot{V} \Delta P}{\eta_{f}}
$$

The heat that can be obtained from HP can be expressed as follows [20]:

$$
\dot{\mathrm{Q}}_{\text {heat pump }}=\dot{Q}_{\text {greenhouse }}-\dot{Q}_{\text {collector }}=\dot{m}_{\text {mix }} c_{p, \text { mix }}\left(T_{\text {mix }, \text { out }}-T_{\text {mix }, \text { in }}\right)
$$

The component that consumes electrical energy in HP system is the compressor. The following Equation can be used to calculate the power of the compressor in designed this greenhouse process [21]:

$$
\dot{W}_{\text {comp }}=\dot{m}_{r}\left(h_{\text {comp }, \text { out }}-h_{\text {comp }, \text { in }}\right)
$$

The refrigerant flowing through the evaporator of HP system reduces the temperature of EGWM water by drawing heat from EGWM. The amount of heat drawn by the evaporator from EGWM can be calculated using the equation below:

$$
\dot{Q}_{\text {evap }}=\dot{m}_{r}\left(h_{\text {evap }, \text { out }}-h_{\text {evap }, \text { in }}\right)=\dot{m}_{\text {mix }} c_{p, \text { mix }}\left(T_{\text {mix.in }}-T_{\text {mix }, \text { evap,out }}\right)
$$

The refrigerant, which has a high temperature and pressure circulating in the condenser of HP, increases the temperature of EGWM by transferring heat to EGWM. The increased temperature of EGWM is circulated in the pipes placed on the greenhouse floor and inside the soil to heat the soil. Amount of heat transferred from condenser in HP system to EGWM: 


$$
\dot{Q}_{c o n}=\dot{m}_{r}\left(h_{\text {con,in }}-h_{\text {con,out }}\right)=\dot{m}_{m i x} c_{p, \text { mix }}\left(T_{m i x, \text { out }}-T_{\text {mix }, \text { evap }, \text { out }}\right)
$$

EGWM coming out of the condenser transfers the heat energy to the soil while heating the soil and at the same time its temperature decreases. Then EGWM comes to the evaporator of HP. Here, the water, whose temperature drops further, comes to the condenser of HP and draws heat. The heat energy transferred from HP to EGWM, which heats the greenhouse soil and ground, can be expressed as below by rewriting again Eq. (17-18).

$$
\begin{gathered}
\dot{Q}_{\text {con }}-\dot{Q}_{\text {evap }}=\dot{m}_{\text {mix }} c_{p, \text { mix }}\left(T_{\text {mix }, \text { out }}-T_{\text {mix.in }}\right)=\dot{m}_{r}\left(h_{\text {comp }, \text { out }}-h_{\text {comp }, \text { in }}\right) \\
\dot{Q}_{\text {heat pump }}=\dot{Q}_{\text {con }}-\dot{Q}_{\text {evap }}=\dot{W}_{\text {comp }}
\end{gathered}
$$

The following equation can be used to calculate the evaporator and condenser surface area to be used in HP:

$$
A_{h x, \text { surface }}=\frac{\dot{Q}_{h x}}{U_{h x} \Delta T_{l n}}
$$

Here $\Delta T_{l n}$ defines the logarithmic temperature difference and is calculated by the equations given below [21]:

$$
\begin{gathered}
\Delta T_{1}=T_{h, \text { in }}-T_{c, \text { out }} \\
\Delta T_{2}=T_{h, \text { out }}-T_{c, \text { in }} \\
\Delta T_{\text {ln }}=\frac{\Delta T_{1}-\Delta T_{2}}{\ln \left(\Delta T_{1} / \Delta T_{2}\right)}
\end{gathered}
$$

The COP of HP system can be calculated with the following equation [18]:

$$
C O P_{h p}=\frac{\dot{Q}_{c o n}}{\dot{W}_{c o m p}}
$$

The mass flow of EGWM circulating in the heating line of the greenhouse can be calculated by rewriting Eq. (15):

$$
\dot{m}_{\text {mix }}=\frac{\dot{\mathrm{Q}}_{\text {heatpump }}}{c_{p, m i x}\left(T_{m i x, o u t}-T_{\text {mix }, \text { in }}\right)}
$$

The flow rate of the circulation pump that transferred EGWM to the greenhouse:

$$
\dot{V}_{\text {pump }}=\frac{\dot{m}_{\text {mix }}}{\rho_{\text {mix }}}
$$

The power of the circulating pump that pumps EGWM into the greenhouse can be calculated with the following equation:

$$
\dot{W}_{\text {pump }}=\frac{\dot{V}_{\text {pump }} \Delta \mathrm{P}}{\eta_{p}}
$$


The heating of the soil and the ground in the greenhouse is supported by the heat energy obtained from HP. The energy balance of HP, which heats the greenhouse floor and soil, can be expressed with the following equation:

$$
\dot{Q}_{\text {heatpump }}=\dot{Q}_{\text {soil }}+\dot{Q}_{\text {floor }}
$$

Heat transfer from the EGWM to the greenhouse and the surface area of the pipe [16]:

$$
\begin{aligned}
& \dot{Q}_{\text {floor }}=\frac{2 \pi L_{\text {pipe }} \Delta T_{l n}}{\frac{1}{h_{i} r_{i}}+\frac{\ln \left(r_{o} / r_{i}\right)}{k_{\text {pipe }}}+\frac{1}{h_{o} r_{o}}}+\left(\varepsilon \sigma A_{b}\left(T^{4}{ }_{\text {pipe }}-T^{4}{ }_{\text {greenhouse }, \text { in }}\right)\right. \\
& A_{\text {pipe }}=\frac{2 \pi L_{\text {pipe }}\left(r_{o}-r_{i}\right)}{\ln \left(r_{o} / r_{i}\right)}
\end{aligned}
$$

The following equation can be used to find the heat transferred from the EGWM to soil for the soil heating [16]:

$$
\dot{Q}_{\text {soil }}=\frac{\Delta T_{l n}}{\frac{1}{h_{i} A_{\text {pipe }}}+\frac{\ln \left(r_{o} / r_{i}\right)}{2 \pi L_{\text {pipe }} k_{\text {pipe }}}+\frac{\mathrm{L}_{\text {soil }}}{k_{\text {soil }} A_{\text {soil }}}}
$$

In PV/T and HP system designed for GH, a new energy system model was created for greenhouses in the frame of Fig. (2-3) by conducting a thermodynamic analysis of the system.

While PV panels convert some of the radiation energy from the sun into electrical energy, some of the incoming radiation is released as heat energy. This heat energy causes the temperature of the PV panel to increase. The voltage values of PV panel decrease due to an increase in PV temperatures. Meanwhile, depending on this voltage drop, the output power of the PV panel diminishes, too. Therefore, it causes the efficiency of the PV panel to decrease. In this case, cooling the PV panel is the best solution. In this designed system, using the PV/T panels, the heat energy obtained by cooling the PV panel is aimed to heat the greenhouse air, and the electricity obtained is intended to meet the electricity required for the greenhouse such as a compressor, fan, pump, the auxiliary heater, etc. in the system. When the solar radiation is sufficient, the greenhouse air will be heated with the heat obtained from PV/T and the surplus electricity produced will be stored in the batteries.

When the solar radiation is insufficient, the auxiliary heater will come into operation. With the designed HP system, the greenhouse soil will remain at a certain temperature and the heating of the greenhouse floor will be supported. In this way, the necessary heat energy of the greenhouse will continuously be supplied without being interrupted. Maintenance costs of PV/T and HP systems are low and this increases the applicability of this system.

\section{RESULT AND DISCUSSION}

In present greenhouses, the use of fossil fuels for heating creates a major challenge both in energy efficiency and environmental impacts. Energy efficiency is important in greenhouses for sustainable agricultural practices. The fact that greenhouses produce their own energy and are sustainable will reduce the costs of agricultural products. With the heating system designed in this study, the desired conditions for the product in the greenhouse will be obtained more appropriately. In this way, the quality of the product will increase.

In this system, which aims to heat both the air and the soil of the greenhouse, the equations that determine the design parameters related to heating were given in detail in the previous section. In Table 3, the studies conducted in the literature for thermal and electrical efficiency of air-based PV/T are presented. 
Table 3. Electrical and thermal efficiencies of air-based PV/T panels

\begin{tabular}{cccccc}
\hline References & Nature of Work & Electrical Efficiency & Thermal Efficiency & Location & Year \\
\hline$[22]$ & Experimental & $17 \%$ & $76 \%$ & Malaysia & 2015 \\
{$[23]$} & Experimental & $15 \%$ & $43.8 \%$ & China & 2015 \\
{$[24]$} & Experimental & $10.6-12.2 \%$ & $28-55 \%$ & Australia & 2012 \\
{$[25]$} & Experimental & $11-12 \%$ & $40-55 \%$ & India & 2008 \\
{$[26]$} & Experimental & $12 \%$ & $36 \%$ & Italy & 2019 \\
{$[27]$} & Experimental & $7.2 \%$ & $69.3 \%$ & China & 2019 \\
\hline
\end{tabular}

As seen in Table 3, when the average electrical efficiency of the air-based PV/T panel is accepted as $12 \%$ and the average thermal efficiency is accepted as $55 \%$, it is understood that the average of $67 \%$ of solar energy can be used. For this reason, the use of PV/T panels provides a great advantage in heating greenhouses. The studies carried out in the literature for COP values of liquid-based heat pump systems are summarized in Table 4.

Table 4. COP values of liquid-based heat pump systems

\begin{tabular}{clcc}
\hline References & \multicolumn{1}{c}{ Type of System } & COP & Year \\
\hline$[28]$ & Water source heat pump & 4.9 & 2019 \\
{$[29]$} & Ethylene glycol water mix source heat pump & 5 & 2020 \\
{$[30]$} & Water source heat pump & 5.9 & 2020 \\
{$[31]$} & Water source heat pump & 4.24 & 2018 \\
{$[32]$} & Ethylene glycol water mix source heat pump & Winter 7.4 / Summer 6.5 & 2017 \\
{$[33]$} & Water source heat pump & 5 & 2020 \\
{$[34]$} & Water source heat pump & 4.9 & 2019 \\
\hline
\end{tabular}

Table 4 shows that the average COP values of water source and ethylene glycol water mix source heat pump systems are between 4.24 and 7.4. This means that these heat pump systems can produce at least 4.24 times more heat than the electricity they consume. In addition, the condenser temperature of the heat pump system from ethylene glycol water mixture can increase up to $69{ }^{\circ} \mathrm{C}$ [29]. In terms of sustainability, energy efficiency, and environmental problems, the use of PV/T and HP systems for greenhouse heating is a very good alternative. The initial investment cost of the PV/T and HP system is high, but energy costs will be minimum in the long run. With this system that produces its own energy, electricity produced from PV/T can be sold when heating is not necessary for the greenhouse. On the other hand, designed and proposed for greenhouse heating, this system can be an eco-friendly alternative considering, the global warming issues.

\section{CONCLUSION}

In this study, a novel heating system, which has PV/T, collectors and HP were designed and recommended for GH. It was aimed to heat the greenhouses in a clean, economical, and sustainable way. A new perspective was introduced in the energy systems by developing a novelty flow design in HP system. PV/T and HP system are a suitable alternative for greenhouse and compared to other fuel heating systems, they are not so costly. Sustainability and economic aspects should be taken into account in the heating of the greenhouse. This system recommended for GH is important for reducing the environmental deterioration. In addition, it will contribute to saving by providing more efficient energy production compared to conventional heating systems. This innovative design, by which agricultural products can be produced with less energy without polluting the environment, will shed light on greenhouse operators. 


\section{REFERENCES}

[1] Max, JFJ, Horst, WJ, Mutwiwa, UN, Tantau, HJ. Effects of greenhouse cooling method on growth, fruit yield and quality of tomato (Solanum lycopersicum L.) in a tropical climate. Scientia Horticulturae 2009; 122(2): 179-186, DOI: 10.1016/j.scienta.2009.05.007

[2] Canakci, M, Emekli, NY, Bilgin, S, Caglayan, N. Heating requirement and its costs in greenhouse structures: A case study for Mediterranean region of Turkey. Renewable and Sustainable Energy Reviews 2013; 24: 483490, DOI: 10.1016/j.rser.2013.03.026

[3] Ahamed, SM, Guo, H, Tanino, K. Energy saving techniques for reducing the heating cost of conventional greenhouses. Biosystems Engineering 2019; 178: 9-33, DOI: 10.1016/j.biosystemseng.2018.10.017

[4] Yatarkalkmaz, MM, Özdemir, MB. The calculation of greenhouse gas emissions of a family and projections for emission reduction. Journal of Energy Systems 2019; 3(3): 96-110, DOI: 10.30521/jes.566516

[5] Esen, M, Yuksel, T. Experimental evaluation of using various renewable energy sources for heating a greenhouse. Energy and Buildings 2013; 65: 340-351, DOI: 10.1016/j.enbuild.2013.06.018

[6] Attar, I, Farhat, A. Efficiency evaluation of a solar water heating system applied to the greenhouse climate. Solar Energy 2015; 119: 212-224, DOI: 10.1016/j.solener.2015.06.040

[7] Yildirim, N, Bilir, L. Evaluation of a hybrid system for a nearly zero energy greenhouse. Energy Conversion and Management 2017; 148: 1278-1290, DOI: 10.1016/j.enconman.2017.06.068

[8] Aye, L, Fuller, RJ, Canal, A. Evaluation of a heat pump system for greenhouse heating. International Journal of Thermal Sciences 2010; 49: 202-208, DOI: 10.1016/j.ijthermalsci.2009.07.002

[9] Joudi, KA, Farhan, AA, Greenhouse heating by solar air heaters on the roof. Renewable Energy 2014; 72: 406414, DOI: 10.1016/j.renene.2014.07.025

[10] Mohsenipour, M, Ebadollahi, M, Rostamzadeh, H, Amidpour, M. Design and evaluation of a solar-based trigeneration system for a nearly zero energy greenhouse in arid region. Journal of Cleaner Production 2020; 254: 119990, DOI: 10.1016/j.jclepro.2020.119990

[11] Baddadi, S, Bouadila, S, Ghorbel, W, Guizani, A. Autonomous greenhouse microclimate through hydroponic design and refurbished thermal energy by phase change material. Journal of Cleaner Production 2018; 211: 360-379, DOI: 10.1016/j.jclepro.2018.11.192

[12] Zhang, L, Xu, P, Mao, J, Tang, X, Li, Z, Shi, J. A low cost seasonal solar soil heat storage system for greenhouse heating: Design and pilot study. Applied Energy 2015; 156: 213-222, DOI: 10.1016/j.apenergy.2015.07.036

[13] Yuksel An. Sera Yapım Tekniği. İstanbul, TURKEY: Hasat Yayıncılık Ltd. Şti., 1995.

[14] Hatfield, JL, Prueger, JH. Temperature extremes: Effect on plant growth and development. Weather and Climate Extremes 2015; 10: 4-10, DOI: 10.1016/j.wace.2015.08.001

[15] Pittenger D. California Master Gardener Handbook. Second ed. Division of Agriculture and Natural Resources, 2014, USA.

[16] Ozturk, AH. Antalya iklimi koşullarında sera 1sıtma amacıyla güneş enerjisinin duyulur 1sı olarak depolanması için tasarım değişkenlerinin belirlenmesi [Determination of Design Variables for the Storage of Solar Energy as Sensible Heat for Greenhouse Heating in Antalya Climate Conditions] Tesisat Mühendisliği 2012; 129: 3850

[17] Zare, D, Minaei, S, Mohamad, ZM, Khoshtaghaza, MH. Computer simulation of rough rice drying in a batch dryer. Energy Conversion and Management 2006; 47: 3241-3254, DOI: 10.1016/j.enconman.2006.02.021

[18] Koşan, M, Demirtaş, M, Aktaş, M, Dişli, E. Performance analyses of sustainable PV/T assisted heat pump drying system. Solar Energy 2020; 199: 657-672, DOI: 10.1016/j.solener.2020.02.040

[19] Karim, MA, Hawlader, MNA. Performance evaluation of a v-groove solar air collector for drying applications. Applied Thermal Engineering 2006; 26(1): 121-130, DOI: 10.1016/j.applthermaleng.2005.03.017

[20] Karaca, G, Dolgun, EC, Koşan, M, Aktaş, M. Photovoltaic-Thermal solar energy system design for dairy industry. Journal of Energy Systems 2019; 3(2): 86-95, DOI: 10.30521/jes.565174

[21] Aktaş, M, Koşan, M, Arslan, E, Tuncer, AD. Designing a novel solar-assisted heat pump system with modification of a thermal energy storage unit. Proc IMechE Part A: J Power and Energy 2019; 233(5): 588603, DOI: $10.1177 / 0957650919847934$

[22] Othman, MY, Tabook, MAS, Sopian, K, Roslan, MH, Ibrahim, Z. An experimental study of PV/T Combi with water and air heating system. Journal of Novel Applied Sciences 2015; 4(6): 725-731, ISSN 2322-5149

[23] Wang, G, Quan, Z, Zha, Y, Sun, C, Tong, J. Performance studies on a novel solar PV/T-air dual heat source heat pump system. Procedia Engineering 2015; 121: 771-778, DOI: 10.1016/j.proeng.2015.09.029

[24] Bambrook, SM, Sproul, AB. Maximising the energy output of a PVT air system. Solar Energy 2012; 86(6): 1857-1871, DOI: 10.1016/j.solener.2012.02.038

[25] Dubey, S, Tiwari, GN. Thermal modeling of a combined system of photovoltaic thermal (PV/T) solar water heater. Solar Energy 2008; 82(7): 602-612, DOI: 10.1016/j.solener.2008.02.005 
[26] Renato, L, Marco, N. Photovoltaic/Thermal (PV/T) ground dual source heat pump: optimum energy and economic sizing based on performance analysis, Energy \& Buildings 2020; 211: 109800, DOI: 10.1016/j.enbuild.2020.109800

[27] Shao, N, Ma, L, Zhang, J. Experimental study on electrical and thermal performance and heat transfer characteristic of PV/T roof in summer. Applied Thermal Engineering 2019; 162: 114276, DOI: 10.1016/j.applthermaleng.2019.114276

[28] Jinzhi, Z, Zishang, Z, Xudong, Z, Yanping, Y, Yi, F, Steve, M. Theoretical and experimental study of a novel solar indirect-expansion heat pump system employing mini channel PV/T and thermal panels. Renewable Energy 2019; 151: 674-686, DOI: 10.1016/j.renene.2019.11.054

[29] Simonetti, R, Molinaroli, L, Manzolini, G. Experimental and analytical study of an innovative integrated dualsource evaporator for solar-assisted heat pumps. Solar Energy 2019; 194: 939-951, DOI: 10.1016/j.solener.2019.10.070

[30] Nina, S, Liangdong, M, Jili, Z. Experimental investigation on the performance of direct-expansion roof-PV/T heat pump system. Energy 2020; 195: 116959, DOI: 10.1016/j.energy.2020.116959

[31] Reda, H, Emam, H, Ming L, Yilian T. The evacuated tube solar collector assisted heat pump for heating greenhouses. Energy \& Buildings 2018; 169: 305-318, DOI: 10.1016/j.enbuild.2018.03.072

[32] Liua, Z, Tan, H, Li, Z. Heating and Cooling Performances of River-Water Source Heat Pump System for Energy Station in Shanghai. Procedia Engineering 2017; 205: 4074-4081, DOI: 10.1016/j.proeng.2017.09.898

[33] Mi, P, Ma, L, Zhang J. Integrated optimization study of hot water supply system with multi-heat source for the public bath based on PVT heat pump and water source heat pump. Applied Thermal Engineering 2020; 176: 115146, DOI: 10.1016/j.applthermaleng.2020.115146

[34] Wang, Z, Wang, L, Ma, A, Liang, K, Song, Z, Feng, L. Performance evaluation of ground water-source heat pump system with a fresh air pre-conditioner using ground water. Energy Conversion and Management 2019; 188: 250-261, DOI: 10.1016/j.enconman.2019.03.061. 